Original studies

Somnologie $2021 \cdot 25: 4-10$

https://doi.org/10.1007/s11818-021-00297-6

Accepted: 13 January 2021

Published online: 19 February 2021

(c) The Author(s) 2021
Angelika A. Schlarb' · Maren-Jo Kater ${ }^{1}$ - Anika Werner ${ }^{1}$ Daniela Hertel' . Friederike Lollies ${ }^{1} \cdot$ Janna Landwehr ${ }^{2}$. Petra Kolip ${ }^{2}$

${ }^{1}$ Fakultät für Psychologie und Sportwissenschaften, Universität Bielefeld, Bielefeld, Germany

${ }^{2}$ Fakultät für Gesundheitswissenschaften, Universität Bielefeld, Bielefeld, Germany

\title{
Sleep apps for children-a critical view
}

\section{Background}

Sleep is-along with healthy nutrition and physical exercise as well as limited or no smoking and the consumption of alcohol-an important pillar of health. However, sleep irritations and sleep disturbances are quite common in young individuals [15]. Moreover, if a young child has sleep disturbances, not only children show various daytime impairments as hyperactivity, depression, and anxiety as well as other side effects as impaired cognitive performance, but also parents of these youngsters report sleeprelated problems and daytime impairments [4]. During the last few years, various sleep trainings or treatment strategies and manuals were developed. These often contain several cognitive behavioural therapy for insomnia (CBT-I)-oriented or CBT-I-based strategies helping the children to calm down, relax and decrease the night-related anxieties or other problems hindering them to fall asleep in the evening or go back to sleep in the night. However, those treatment options are not always easy to access. Especially parents with several children often have little spare time or time-schedules which do not allow use of counselling or treatment options with personal presence. Therefore, online treatments are very welcome in those parents as they are time-saving and easy to access. Previous studies showed that online treatment was as effective as on-sight treatment for parents of young children. In an own study, published in 2012, 55 children aged 8-57 months with insomnia participated in the 6-week Mini-KiSS online treatment [14]. The training was highly accepted by parents, and they also felt more competent to deal with sleep-related problems of their child afterwards. Parental dysfunctional strategies were reduced such as staying or soothing the child until it fell asleep. Furthermore, sleep-related problems were reduced, especially frequency and duration of night wakings as well as the need for external help to start or maintain sleep during night decreased. Nearly the same results were found in another study with more children and their primary caregivers based on nearly 200 mothers and fathers. Both primary caregivers reported enhanced psychosocial health and less maladaptive coping (rumination, self-blame) after treatment. In this study, we found also that additional personal telephone support rarely affected the results [5].

A just recently published study of Hiscock et al. [10] also evaluated effects of a digital sleep intervention. In their study, 120 families with 2- to 13-year-old children, suffering from behavioural sleep problems, participated. Primary caregivers received age-oriented behavioural sleep strategies via a smart phone app and complementary website. Sleep-related data were assessed before and after digital sleep intervention which took 5 weeks. Based on caregiver report, fewer children suffered from sleep problems (84.6 compared to $40.7 \%$ ) afterwards. This was accompanied by improved mental health and also improved caregiver mental health, whereas caregiver sleep quality and quantity remained unchanged.

However, these studies were online treatment studies and not conducted based on apps only. As apps are more and more common in various fields of health, including physical activity, healthy nutrition or smoking sensation $[1,18]$, they provide easy access for individuals at risk for diseases or suffer from diseases. Given recent estimates that approximately $97 \%$ of German households use a mobile phone [7], and more than $78 \%$ of Germans own a mobile phone [2], apps are an excellent strategy to reach families with a need for sleep help. Although sleep apps for parents of children are very often used in bedtime routine [17] and popular as commercially health apps, little is known about these apps in detail.

Based on the literature we wanted to examine the existence and usage of sleep apps for babies and children. We hypothesized that (a) there exist many sleep apps for children, and (b) apps are widely downloaded/used by primary caregivers. In addition, we will exploratively assess the contents of the apps and other facets like age-orientation.

\section{Methods}

\section{Procedure}

An online search using the search strings "sleep/Schlaf" and "app" and "baby" or "child/Kind" in Google Play Store and Apple App Store up to September 2020 was initiated. The apps were scored based on various aspects as category (sounds, stories, etc.), valuation scores, and age-orientation (information regarding consumers). In addition, declared training apps were qualitatively proved by three authors regarding declared addressed age, contents as well as technical requirements. 


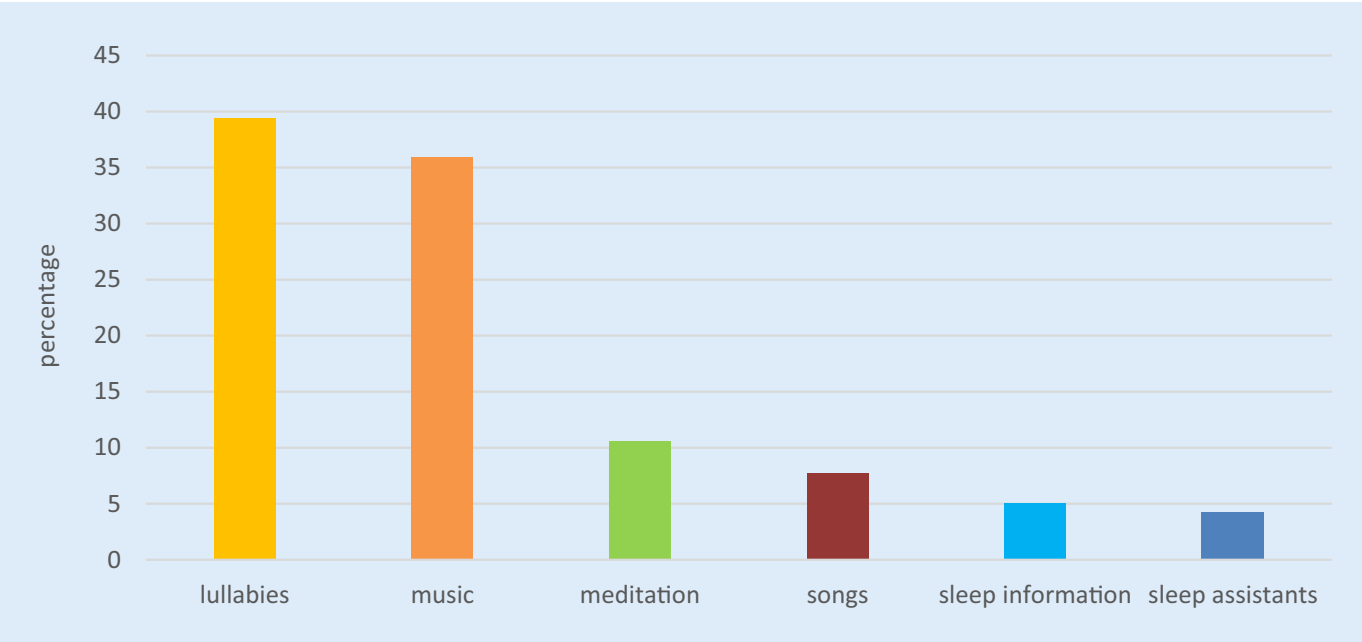

Fig. $1<$ Types of sleep apps for children

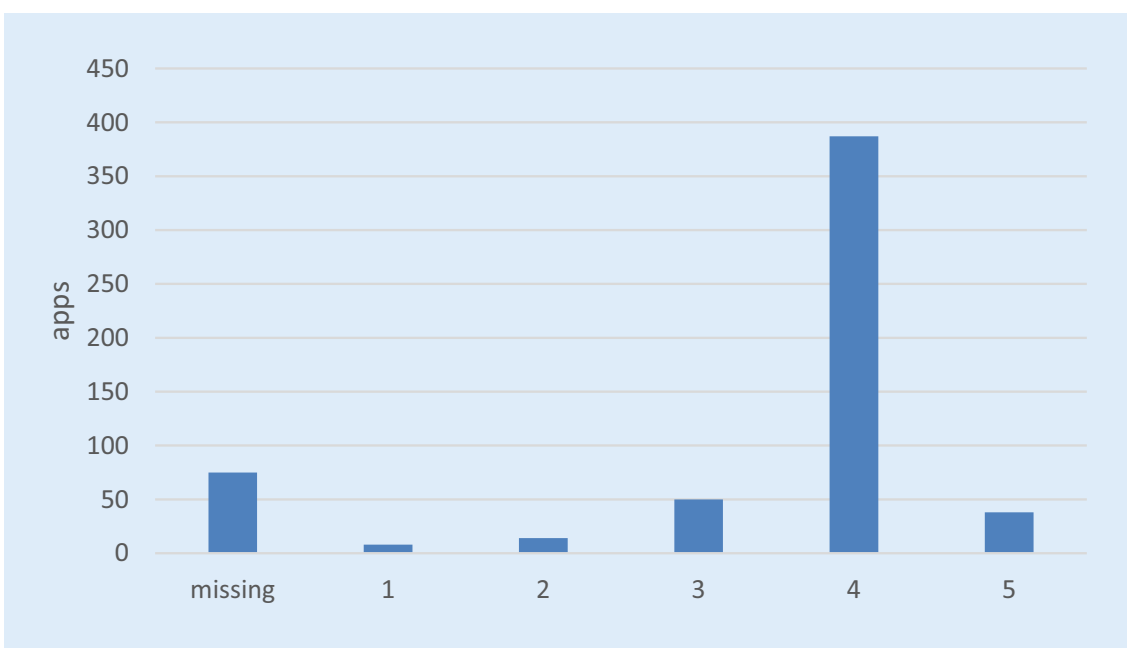

Fig. $2 \Delta$ Frequency of valuation scores for the children sleep apps. (Note: higher scoring means better)

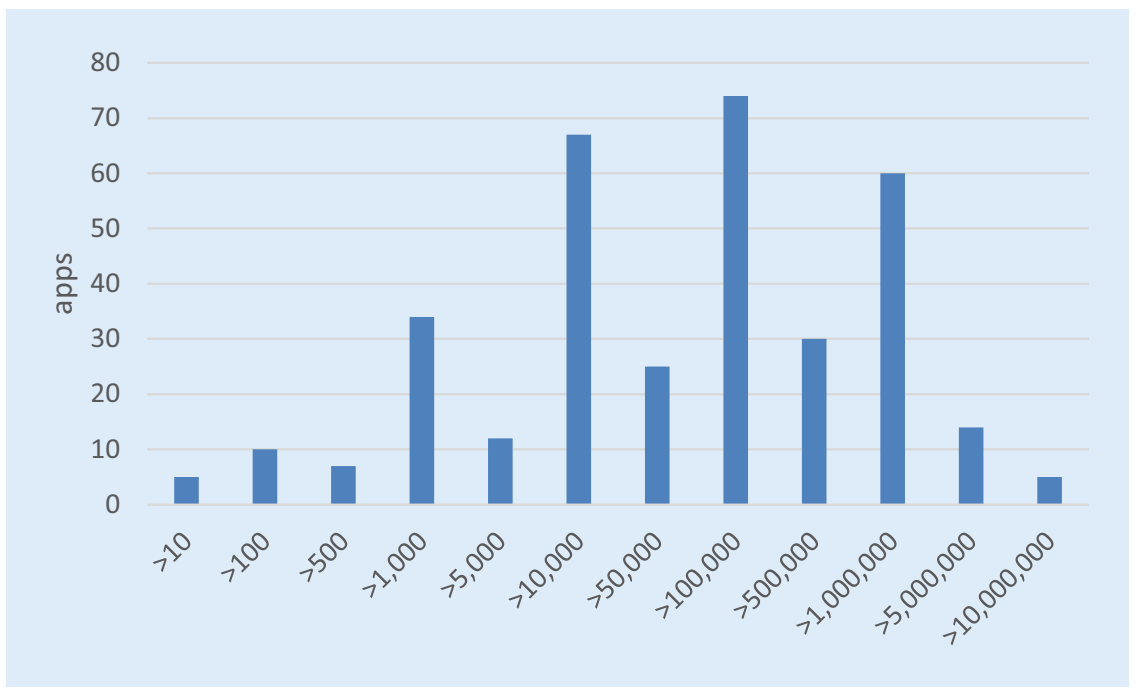

Fig. $3 \Delta$ Frequency of installations for children sleep apps

\section{Results}

A total of 573 sleep apps based on the above-described search strings were found. However, 88 of the apps (15.4\%) were not specifically declared for children although the search was performed using the above-described strings.

\section{Contents}

Of these 573 sleep apps 226 (39.4\%) apps contained lullabies (• Fig. 1), 206 apps (35.9\%) declared themselves to use sleep-oriented music, 44 apps (7.7\%) used songs, 10 apps used rain noises for sleep help, 61 apps (10.6\%) used meditation as sleep help (according to their description), 29 apps (5\%) integrated sleep-related information, and 24 (4.2\%) described themselves as assistants and help regarding sleep monitoring. Furthermore, 7 apps used mindfulness based strategies, 5 apps declared themselves as based on relaxation techniques, whereas only 3 apps $(0.5 \%)$ used training strategies and further 7 apps (1.2\%) were declared as sleep trainer.

\section{Valuation}

Valuation scores varied between zero, 31 apps had one valuation, 283 apps (49.4\%) had more than 100 valuation scores and 179 (31.2\%) more than 1000 valuation scores with the highest based on 352,090 scores. For 72 no scores were available. The highest scores were 5, whereas the lowest score were given 
with $1(n=8)$. In all, 387 had a score between 4 and 5, and 38 apps had a score of 5 . However, some of these were valuated by only one person (• Fig. 2).

\section{Installation frequencies}

Some apps $(n=19)$ were installed more than 5,000,000 times-these were mostly sounds and/or music apps. However, for 226 apps no information regarding installation quote was available, 5 apps were installed more than 10 times, 10 apps were downloaded 100 times, 7 apps more than 500 times, 34 apps 1000 times, 12 apps more than 5000 times, 67 apps 10,000 times, 25 more than 50,000 times, 74 for 100,000 times, 30 more than 500,000 times, 60 for 1,000,000 times, 5 apps for more than 10,000,000 times (• Fig. 3).

\section{Costs}

For 220 apps (38.4\%) no price was declared, 16 apps costed less than $1 €, 47$ were cheaper than $2 €, 90$ costed less than $5 €$, further 12 less than $10 €$. However, the most expensive app costed $349.99 €$.

\section{Qualitative analysis of the training apps $(n=7)$}

\section{"Raising Children"}

The English speaking app "Raising Children" addresses different topics for helping parents to raise their children (e.g. breast feeding, sleep, infant interaction). With regard to sleep, it provides practical advice for different age groups (newborns, infants, crawlers, toddlers, 2-yearolds, preschoolers, and primary school children). In general, it can be summarized that many aids are helpful for parents. However, it must be mentioned that some misleading information is also provided (e.g. that parents should decide for themselves whether their child falls asleep alone or with their help) which is not in line with the current recommendations. Or that "many babies need to be parented to sleep" with the help of rocking the child by the parents etc.

\section{"Baby+"}

Baby Plus is an app in which parents can record and log their child's behaviour and

Somnologie $2021 \cdot 25: 4-10$ https://doi.org/10.1007/s11818-021-00297-6

(c) The Author(s) 2021

\section{A. A. Schlarb · M.-J. Kater · A. Werner · D. Hertel · F. Lollies · J. Landwehr · P. Kolip} Sleep apps for children-a critical view

\section{Abstract}

Background. During the last few years, technology support for various health-related areas is becoming increasingly common. Not only are nutrition apps or sports apps available, but apps regarding sleep are also available. As the prevalence of sleep disturbances in infancy and childhood is quite high, supportive strategies are necessary to help families to sleep healthy. Thus, this study addresses the topic of sleep apps for babies and children.

Methods. Sleep apps were searched using different strings. Age-oriented apps were scored using different criteria which were theoretically based (e.g., description, costs, downloads).

Results. We found 573 sleep apps using the Apple App Store and Google Play Store with the search strings "sleep" and "app" and "baby" or "children". Of these, $15.4 \%$ were not declared for children or babies. Content of most apps was lullabies or music and songs. Sleep-related aspects as sleep information or sleep education was very rare.

Conclusions. There is a new field of sleep help-with sleep apps used by families. Because of the high prevalence concerning sleep problems, the market concerning sleep helping apps is well used. However, most of the sleep apps did not have declarations concerning age and other factors. Parents should be careful using sleep apps for their offspring.

Keywords

Sleep apps · Sleep hygiene · Infant sleep problems · Sleep help · Sleepiness · Software

\section{Schlaf-Apps für Kinder - ein kritischer Blick}

\section{Zusammenfassung}

Hintergrund. Während der letzten Jahre hat sich technologische Unterstützung in verschiedenen gesundheitsbezogenen Bereichen zunehmend verbreitet. Nicht nur Ernährungs-Apps oder Sport-Apps, sondern auch Apps für den Schlaf sind verfügbar. Da die Prävalenz von Schlafstörungen bei Säuglingen und Kindern ziemlich hoch ist, sind unterstützende Maßnahmen erforderlich, um Familien zu einem gesunden Schlaf zu verhelfen. Daher richtet sich in der vorliegenden Studie das Hauptaugenmerk auf Schlaf-Apps für Babys und Kinder. Methoden. Schlaf-Apps wurden unter Verwendung verschiedener Zeichenfolgen gesucht. Altersorientierte Apps wurden nach unterschiedlichen Kriterien, die theoretisch begründet waren (z. B. Beschreibung, Kosten, Downloads), bewertet.

Ergebnisse. Es fanden sich 573 Schlaf-Apps im Apple App Store und Google Play Store mit den Suchbegriffen "sleep" und "app" und "baby" oder "children". Davon waren $15,4 \%$ nicht für Kinder oder Babys deklariert. Inhalt der meisten Apps waren Wiegenlieder oder Musik und Lieder. Schlafbezogene Aspekte wie Informationen zum Schlaf oder Aufklärung über den Schlaf waren sehr selten. Schlussfolgerung. Es gibt einen neuen Bereich der Hilfen zum Schlaf - mit Schlaf-Apps, die von Familien verwendet werden. Wegen der hohen Prävalenz von Schlafstörungen ist der Markt im Bereich der Schlafhilfe-Apps stark frequentiert. Jedoch enthielten die meisten der Schlaf-Apps keine Hinweise zu Alter und anderen Faktoren. Eltern sollten bei der Verwendung von Schlaf-Apps für ihren Nachwuchs Vorsicht walten lassen.

\section{Schlüsselwörter}

Schlaf-Apps · Schlafhygiene · Schlafstörungen bei Säuglingen · Schlafhilfen · Schläfrigkeit . Software developmental steps (e.g. height, sleep, meals). In the sleep section, the app enables parents to record their child's sleep times. The app was originally developed for parents of 1-year-old children, but can also be used beyond that. It further contains small text articles that provide various information (e.g. for a safe home environment for newborns).

\section{“REMI-Babyphone, Sleep}

\section{Trainer"}

The app requires an additional device which is to place next to the infant's bed 
Hier steht eine Anzeige.

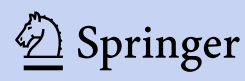


and acts as a loudspeaker, alarm clock and lighting. Additional costs are $89 €$.

\section{"Sleeprate: Improve your sleep"}

This app is more for adolescents and adults than for infants or children. The advertised sleep training program must be purchased for $95 €$ per year. Furthermore, without the additional program the app can only be used as a sleep tracker.

\section{"Infant Sleep Info"}

The app focuses on information about sleep safety to prevent sudden infants' death syndrome (SIDS). Therefore the app provides knowledge about different sleeping positions and related risks as well as important parenting behaviour. Positively, the tone is neutral and nonjudgmental which is important to improve parents' acceptance especially when deadly dangers are displayed. A sleep $\log$ is integrated to monitor the infants sleep duration.

\section{"baby sleep problems"}

Although our study was completed over a period of 12 weeks-this app was no longer available at the time of qualitative research.

\section{"Babywink"}

This app is a detailed sleep assessment and training program. Prior to training, the parents have to have their baby's sleep checked by a paediatrician to ensure that no other reason might be responsible for the child's sleep difficulties. Furthermore, the sleep pattern of the child is assessed for 3 days. Afterwards a sleep training program tailored to the child's and family's needs is derived. They declare that the app is constructed on Michel Gradisars research; however, the babywink team is comprised of only engineers. The authors declared that the app might be for newborns but the ideal age is 6 months and more. Costs of the account is 49.98 US\$ per year.

\section{"Sleep Trainer"}

This training is based on the Ferber method. Based on seven steps from feeding prior to bedtime up to checking after $15 \mathrm{~min}$ if the baby is crying, the steps are clearly described.

\section{Discussion}

In this study we examined the existence and usage of sleep apps for babies and children. As modern sleep specialists are more and more questioned by parents concerning sleep help and apps, knowledge regarding some basic information might be helpful. Without data many paediatric sleep specialists and psychotherapists might be unsure about recommendation of these technologies for parents. Beyond, providers may influence due to such apps the parental sleeprelated behaviour and self-treatment of children's sleep problems without any scientific verification. We hypothesized based on previous studies that there is a wide range of sleep apps for children, and that they show high download rates. In addition, further aspects like contents and age-orientation were assessed. As sleep is very important for physical and mental health, it is not surprising that a wide range of sleep apps for parents with babies and children is available. As demonstrated in another study [17], parents of children without sleep problems often use apps to settle their child to sleep, whereas parents with children suffering from sleep problems more often use physical comforting strategies. However, one might anticipate that parents use apps before they engage more intensely into bed settling strategies.

In this review, we found only a few apps including sleep-related information or sleep hygiene and parental behaviour recommendation, whereas the greater percentage of apps were based on music or sounds. These results are in line with another study concerning children's sleep books [16]. However, using sleep apps might help concerning sleep disorder prevention or early intervention. As Hiscock and colleagues [10] showed, the use of health services (averaged over a 6-month period pre- and post-intervention) fell from $18.9 \%$ pre- to $14.1 \%$ postintervention after sleep treatment. However their study addressed families with children suffering from behavioural sleep problems. They summarized that digital sleep intervention can improve sleep in children with moderate/severe behavioural sleep problems, and also caregiver mental health. Therefore, it may be a useful alternative to face-to-face management of behavioural sleep problems. Although publications concerning those new technologies are rare, more recent studies showed that apps for youngsters might also be helpful for orientation concerning usability in young age. For example, as a recently review showed, apps can help or support children concerning learning. Griffith et al. [8] conducted a systematic review whether young children can learn from interactive apps. They included 35 studies based on children younger than 6 years and found that this young age group can learn for example mathematics. However, researchers did not find effects concerning apps addressing social communication skills.

Further apps also address child health behaviour. For example Zotti et al. [19] evaluated the effectiveness of apps in improving oral hygiene in children between 4 and 7 years. Children using the app had better oral hygiene and less plaque than the control group which was not using the app. The authors concluded that apps in young children are effective for oral hygiene. However, there is a need for further studies for this young age.

Furthermore, apps for adults are very common for example concerning pregnancy and child development $[6,13]$ showing that nearly three quarters used a pregnancy app and about 50\% using at minimum one parenting app.

\section{Sleep evaluation app and apps for sleep help}

Whereas sleep evaluation apps regarding assessment of children's sleep are more and more available; however, validation is often missing. Heng et al. [9] for example developed and used a web app for evaluation of Sleep-Wake Behaviour Application (SWAPP) of children (with mental diseases). Assessment with this app allows the caregivers of children to log sleep and daytime activities and share these data with experts-for example paediatricians and other health care professionals. Based on such apps diagnostics and treatment adherence might be easier according to the authors. However, Lorenz and Williams [12] concluded that 
validation studies concerning sleep apps are necessary to assess adequately various sleep parameters. In addition, most studies examining sleep apps have concentrated on the accuracy of the apps (e.g. polysomnography or actigraphy) to measure sleep items as onset latency or night wakings $[3,11]$, whereas the study at hand had another focus and gives an overview of the contents of sleep apps for children. In sum, although there are a large number of apps concerning sleep for babies or children, a very small number is addressing sleep per se. Most apps are music- or sound-based and only a couple of apps are training apps. As the above qualitative examination shows, the apps are often cost intensive or contain misleading information, others are structured and recommend prior sleep checking by a paediatrician but the staff members are not sleep experts or paediatricians. In addition, evaluation studies as for online therapy are missing.

\section{Limitations}

Limitations of this report should be also mentioned. First, the search strings were simple and other ways of searching for sleep apps maybe also effective. However, concerning the search strategy we were in line with previous publication addressing sleep apps per se [11]. Furthermore, we did not have all information regarding the apps to fully assess technical aspects in detail. In future studies detailed analysis with more information concerning age, usage etc. is necessary. Finally, due to the rapid evolution of sleep apps this is only a snapshot of the available sleep apps for young age.

\section{Conclusions}

Sleep apps for children are increasingly used by parents. These apps might have the potential to help families sleep well and to promote sleep education and healthy sleep habits. However, to date most apps use music or sounds to facilitate sleep. A large number of scientific questions concerning clinical significance and the effect on the sleep of the children remain unanswered. The paediatric sleep specialists, researchers and educational experts should focus on these new technologies and evaluate their effects.

\section{Corresponding address}

Prof. Dr. Angelika A. Schlarb

Fakultät für Psychologie und

Sportwissenschaften, Universität

Bielefeld

Universitätsstraße 25, 33501 Bielefeld,

Germany

Angelika.schlarb@uni-bielefeld.de

Funding. Open Access funding enabled and organized by Projekt DEAL.

\section{Compliance with ethical guidelines}

Conflict of interest. A.A. Schlarb, M.-J. Kater, A. Werner, D. Hertel, F. Lollies, J. Landwehr and P. Kolip declare that they have no competing interests.

For this article no studies with human participants or animals were performed by any of the authors. All studies mentioned were in accordance with the ethical standards indicated in each case.

Open Access. This article is licensed under a Creative Commons Attribution 4.0 International License, which permits use, sharing, adaptation, distribution and reproduction in any medium or format, as long as you give appropriate credit to the original author(s) and the source, provide a link to the Creative Commons licence, and indicate if changes were made. The images or other third party material in this article are included in the article's Creative Commons licence, unless indicated otherwise in a credit line to the material. If material is not included in the article's Creative Commons licence and your intended use is not permitted by statutory regulation or exceeds the permitted use, you will need to obtain permission directly from the copyright holder. To view a copy of this licence, visit http://creativecommons.org/licenses/by/4.0/.

\section{References}

1. Abroms LC, Westmaas JL, Bontemps-Jones J, Ramani R, Mellerson J (2013) A content analysis of popular smartphone apps for smoking cessation. Am J Prev Med 45:732-736. https://doi.org/10. 1016/j.amepre.2013.07.008

2. Ametsreiter H (2017) Smartphone-Markt: Konjunktur und Trends. https://www.bitkom.org/ sites/default/files/201902/BitkomPressekonferenz \%20Smartphone-Markt\%2020\%2002\%202019 $\% 20 \mathrm{Pr} \%$ C3\%A4 sentation_final.pdf. Accessed 10 Jan 2020

3. Bhat $S$, Chokroverty $S$, DeBari VA, Ferraris A, Gupta D, Gushway-Henry N, Gowda SP, Polos PG, Rubenstein M, Seidu H, Mozafarian M (2015) Is there a clinical role for smartphone sleep apps? Comparison of sleep cycle detection by a smartphone application to polysomnography. JClin Sleep Med 11:709-715

4. Brandhorst I, Bernhardt C, Hautzinger M, Schlarb AA (2017) Die Cortisol-Aufwachreaktion bei Müttern junger Kinder mit Schlafproblemen. Somnologie 21:53-66

5. Brandhorst I, Hautzinger M, Schlarb AA (2016) Improving psychosocial health, coping, and selfefficacy in parents of sleep-disturbed young children.J Psychol Psychother 6:1000249

6. Dalton JA, Clifton VL, Humphreys S, Roberts $C T$, Rodger D, Skuse A, Wilmore M (2018) The health-e babies app for antenatal education: feasibility for socially disadvantaged women. PLOS ONE 13:e194337. https://doi.org/10.1371/journal. pone. 0194337

7. Destatis (2018) Datenreport 2018 - Sozialbericht für Deutschland, Gesamtausgabe. https:// wwwdestatis.de/DE/Service/Statistik-Campus/ Datenreport/Downloads/datenreport-2018html. Accessed 10 Jan 2020

8. Griffith SF, Bagner DM, Hagan MB, Heflin BH, Heymann P (2020) Apps as learning tools: a systematic review. Pediatrics 145:1-14. https:// doi.org/10.1542/peds.2019-1579

9. Heng TB, Gupta A, Shaw C, Raber C, Schilling M, Chen N, Peng D, Zhao B, Ipsiroglu O, Berger M, Beyzaei N (2018) Sleep-wake-behaviour app: towards developing a database for informing e-coaching solutions for neurodevelopmental disorders in children. In: Proceedings of the 12th EAl international conference on pervasive computing technologies for Healthcare, $p p$ 371-377

10. Hiscock H, Ng O, Crossley L, Chow J, Rausa V, Hearps S (2020) Sleep well be well: pilot of a digital intervention to improve child behavioral sleep problems. J Paediatr Child Health. https://doi.org/ 10.1111/jpc.15106

11. Ko PR, Kientz JA, Choe EK, Kay M, Landis CA, Watson NF (2015) Consumer sleep technologies: a review of the landscape. J Clin Sleep Med 11:1455-1461

12. Lorenz CP, Williams AZ (2017) Sleep apps: what role do they play in clinical medicine? Curr Opin Pulm Med 23:512-516

13. Lupton D, Pedersen S (2016) An Australian survey of women's use of pregnancy and parenting apps. Women Birth 29:368-375. https://doi.org/10. 1016/j.wombi.2016.01.008

14. Schlarb AA, Brandhorst I (2012) Mini-KiSS Online: an Internet-based intervention program for parents of young children with sleep problems-influence on parental behavior and children's sleep. Nat Sci Sleep. https://doi.org/10. 2147/NSS.S28337

15. Schlarb AA, Gulewitsch MD, Weltzer V, Ellert U, Enck P (2015) Sleep duration and sleep problems in a representative sample of German children and adolescents. Health 7:1397-1408

16. Schlarb AA, Landwehr J, Kater M-J, Werner A, Cattarius B, Schneider B, Genuneit J, Jud A, Kolip P (2020) Wenn die Schlaffee schlecht zaubert - eine kritische Analyse der Kinderbücher zum Thema Schlafen. Somnologie 24:229-236. https://doi. org/10.1007/s11818-020-00278-1

17. Schlarb AA, Seiler D, Werner A, Kater M-J (2020) Modern strategies to settle infants off to sleep-a comparison between sleep-disturbed infants and non-sleep-disturbed infants. Somnologie 24:237-244

18. Schoffman DE, Turner-McGrievy G, Jones SJ, Wilcox S (2013) Mobile apps for pediatric obesity 
prevention and treatment, healthy eating, and physical activity promotion: just fun and games? Behav Med Pract Policy Res 3:320-325

19. Zotti F, Pietrobelli A, Malchiodi L, Nocini PF, Albanese M (2019) Apps for oral hygiene in children 4 to 7 years: fun and effectiveness. J Clin Exp Dent 11:795-801. https://doi.org/10.4317/ jced.55686

\section{"Magst du Schokolade?»}

Über Kommunikationsfähigkeiten von

Menschen im REM-Schlaf

Mit schlafenden Versuchspersonen lassen sich komplexe Nachrichten austauschen. Das haben Forschende des Instituts für Kognitionswissenschaft der Universität Osnabrück gemeinsam mit internationalen Kolleglnnen jetzt in Studien gezeigt.

"Träume entführen uns in eine andere Realität, eine halluzinatorische Welt, die sich ebenso real anfühlt wie jede wache Erfahrung«, erklärt Dr. Appel von der Universität Osnabrück. »Diese oft bizarren Episoden sind sinnbildlich für den menschlichen Schlaf, aber noch nicht hinreichend verstanden. Retrospektive Traumberichte wiedererwachter Menschen unterliegen der Verzerrung und dem Vergessen, was eine grundlegende Herausforderung für wissenschaftliche Untersuchungen des Träumens darstellt.» Die Methode des Interactive Dreaming, also der geleitete Austausch zwischen einer träumenden und einer wachen Person, ebnet als vielversprechender Ansatz neuen Forschungen den Weg.

Die kognitionswissenschaftliche Studie zeigt, dass Personen, die sich während des REM-Schlafes ihres Traumzustandes bewusst waren, in der Lage waren, die Fragen eines Experimentators zu verstehen und ihm Antworten geben. Die Forschenden machten sich dabei den Effekt zunutze, dass Wachwelt-Stimuli wie Töne, Lichtblinks und Tappen auf den Handrücken teilweise in Träume inkorporiert werden, d.h. dort direkt oder indirekt eingebaut werden und vom Träumer erkannt werden können.

Die Antworten auf die Fragen gaben die Versuchspersonen über Augenbewegungen oder Kontraktionen der Gesichtsmuskel auch dies lässt sich bis zu einem gewissen Grad aus dem Traum heraus willentlich ansteuern und im Schlaflabor aufzeichnen. Dabei demonstrierten einige der insgesamt 36 Versuchspersonen zahlreiche Fähigkeiten Dazu gehörten das Erkennen der WachweltInformationen im Traum, die Analyse dieser Informationen (z. B. Fragen wie: "Magst du Schokolade?"), die Speicherung dieser Informationen im Arbeitsgedächtnis, das Berechnen einfacher Antworten und das willentliche Übermitteln dieser Antworten. Auf diese Weise konnten sechs Versuchungspersonen in 29 Fällen Fragen korrekt beantworten.

Die Schlaflabor-Experimente wurden an der Universität Osnabrück, der Northwestern University (Chicago/USA), der Sorbonne (Paris/FR) und der Radboud Universität (Nijmegen/NL) durchgeführt - unabhängig voneinander in vier Forschungsgruppen mit leicht unterschiedlicher Methodik, aber stets dem gleichen Ergebnis - und anschließend als Multi-Center-Studie zusammengefasst. Der deutsche Teil der Studie wurde dabei finanziell von der Hans-Mühlenhoff-Stiftung Osnabrück unterstützt.

»Wir haben die Ergebnisse zusammengefügt, weil wir der Überzeugung sind, dass die Kombination von Ergebnissen aus vier verschiedenen Laboren mit unterschiedlichen Ansätzen die Realität dieses Phänomens am überzeugendsten belegt", sagt Karen Konkoly, Doktorandin an der Northwestern University in Chicago und gemeinsam mit Appel Erstautorin der Arbeit. »Und wir sehen, dass es tatsächlich unterschiedliche Wege gibt, diese bi-direktionale Kommunikation durchzuführen.»

Die potenziellen Anwendungen des Interactive Dreaming außerhalb der Forschung seien mannigfaltig, so Appel. Psychotherapeuten böte sich die Möglichkeit, Albträume direkt während des Auftretens zu behandeln. Neues Wissen 'im Schlaf' zu lernen - der Traum vieler Schüler - sei genauso denkbar wie das Training neuer musikalischer oder sportlicher Fähigkeiten oder das Nutzen der Methode für privates Entertainment. Zunächst müsse allerdings das Interaktive Träumen weiter erforscht und verbessert werden, so der Osnabrücker Kognitionswissenschaftler.

Originalpublikation: Current Biology, Konkoly et al.: "Real-time dialogue between experimenters and dreamers during REM sleep" https://www.cell.com/current-biology/fulltext/S0960-9822(21)00059-2 DOI: 10.1016/j.cub.2021.01.026

Quelle: Universität Osnabrück (www.uni-osnabrueck.de [18.02.2021]) 